\title{
NIGERIA'S 2015 ELECTIONS: \\ Permanent voter's cards, smart card readers \\ and security challenges
}

\author{
Aremu Fatai Ayinde and Aluko Opeyemi Idowu \\ Aruma Fatai Ayinde is an Associate Professor in the Political Science \\ Department University of Ilorin, Nigeria \\ email: taifaother@gmail.com
}

\begin{abstract}
Aluko Opeyemi Idowu is a PhD candidate in the Political Science Department University of Ilorin, Nigeria

email: opealukoheavenprogress@gmail.com
\end{abstract}

\begin{abstract}
Voting time in any democracy always involves rigorous politicking. The electioneering exercise in developed democracies tends to have less tension in the polity than in many developing democracies which do witness some hitches, mainly in issues of procedure and security. However, these problems reduce with every subsequent election. Nigeria's 2015 general elections were no exception to such improvements as there were innovations in the Anti Electoral Fraud Procedures (AEFP). The research in this work questions the extent to which the AEFP prevented electoral malpractices in Nigeria's 2015 general elections. It also assesses whether, given the security tension in the country, the ratio of actual voter turnout to registered voter speaks of peace in the electoral process. The research methodology adopted is an empirical analysis of data from the Afrobarometer Round 6 survey assessing Nigerians' perceptions of their electoral environment and of the level of preparedness of the Independent Electoral Commission (INEC). INEC's officially released presidential election result is also critically interrogated. The relative deprivation theory is used to analyse the causes of security challenges. The conclusion is premised on the grounds that there were general improvements in the 2015 general elections and recommendations were posited to the Election Management Body (EMB), the government and the general masses.
\end{abstract}

Key Words: election, democracy, permanent voter's card (PVC), card reader, urban violence, INEC 


\section{INTRODUCTION}

Election time in any democracy is always a period of rigorous politicking. All the stakeholders, such as the election management body (EMB), the political parties, the electorate and the government have their hands full ensuring that the exercise is successful. The EMB is responsible for the conduct of a free and fair election, the political parties are responsible for the contest for available political offices, the electorate is responsible for voting their preferred candidates into office, and the government is responsible for maintaining a level playing field for all stakeholders.

Elections are a universally acceptable process of legitimising a government. In developed democracies, there is usually less tension in the polity than in developing democracies. Election periods are seen as a time to reward representatives who have served in function and in office in equal measure to their performances (Abdullahi 2015; Goldsmith 2015; Butts and Metz 2015). This therefore creates an oppoortunity to check and balance both the political parties and the candidates vying for political offices. This power of the electorate to choose between political parties and candidates in highly competitive campaigns, but in a peaceful and rational manner, speaks of the developed democracies such as Britain, the United State of America, France and Germany.

On the other hand, the electioneering exercise in developing democracies does, in many cases, witness some hitches mainly regarding procedures, technical and security issues. The reason for this is that these nations have recently emerged from either colonial rule, military dictatorship or some other form of autocratic regime, including a one-party state. Those groups that emerge out of the politics of personal aggrandisement, subjugation and manipulation, regardless of whether they are ethnic, religious or other, will be in perpetual conflict with the polity. Therefore they use all possible means including the politics of anger, force and violence, to liberate themselves (Lauren 2015; National Human Rights Commission of Nigeria 2015). However, this political rush and the forceful emancipation of political power abates with every subsequent election. Most countries in Africa, Asia, the Middle East and a few in Latin America fall into this category.

Nigeria's 2015 general elections also experienced improvements in procedures and fairness when compared with the previous elections. There were innovations in the Anti-Electoral Fraud Procedures (AEFP) such as the smart card reader and the permanent voter's card, which has microchips for a technical analysis of card-holder identity. This helps to reduce electoral malpractices to an acceptable minimum and therefore consolidates and improves the democratic process in the country. It also negates the previous elections conducted in the country which were characterised by multiple voting, underage voters, voter impersonation, ballot stuffing, ballot snatching, irregular accreditations of political 
parties, candidates and electorates, and general security imbroglios (Omotola, 2010; National Democratic Institute, 2012).

This research considers the extent of improvements such as the electronic card reader and the permanent voter's card (PVC) introduced by the AEPF into the conduct of the 2015 general elections in Nigeria, using the presidential election as a yardstick. It further considers the security threat to and tensions of the electorate by comparing the ratio of registered voters to the accredited voters who actually voted. The research questions thus posited in this work are; to what extent did the AEFP reduce electoral malpractice in Nigeria's 2015 general elections; and, considering the actual voter turnout as a percentage of the registered electorate, whether this indicates a level of insecurity or political tension in Nigeria's electoral space.

The relative deprivation theory is used to analyse the reasons behind political tension and crises in most developing democracies and some developed democracies. In this study it is also used to analyse the causes of security challenges in the polity. The research methodology adopted is an empirical analysis of data from the Afrobarometer Round 6 survey on Nigerians' perceptions of their electoral environment and on the INEC's level of preparedness for the election. INEC's officially released presidential election result is also critically interrogated.

The conclusion is premised on the grounds that, unlike the previous elections in Nigeria in 1993, 1999, 2003, 2007 and 2011, there have been general improvements in the 2015 general elections. Subsequent elections in the country are forecast to have improved election processes. Recommendations were directed to the electoral body, the government and the general masses on the need to engage in politics without tears and to have freer and fairer elections in the country.

\section{DEMOCRACY AND ELECTIONS IN NIGERIA}

Since independence in 1960 Nigeria has been a deeply divided multi-ethnic state. The quest for establishing democratic government has swept across the polities of the world checking undemocratic regimes, and in 1999 Nigeria also had its fair share of this democratic wave. The cardinal point in every democracy is the right of the citizens to choose who they want to govern them from many options and alternatives (Gyimah-Boadi, 2015). Since the advent of democracy in Nigeria in 1999, there has been a growing desire for people to exercise their legitimate right to vote and be voted for. This has led to several crises and clashes of interest between different factions in Nigeria such as ethnic and religious sectors.

All elections conducted in Nigeria since independence have generated untold controversies and bitterness on a national scale. This is because of the Siamese 
twins of electoral fraud and mass violence that have become central elements in both the history of elections and of the electoral process in the country (Gberie, 2011; National Democratic Institute, 2012). Despite the marked improvement in the conduct of the 2011 elections, the process was not free from malpractices and violence (Omotola, 2010; Gberie, 2011).

Thus over the years the electoral processes in Nigeria's democratic governance have continued to be marred by malpractice, such as extraordinary displays of rigging, ballot snatching at gun point, violence and acrimony, thuggery, boycotts, threats and criminal manipulations of the voters list, falsification of election results, the use of security agencies against political opponents and the intimidation of voters (Omotola, 2010; Jega and Hillier 2012; National Democratic Institute, 2012). These did not strengthen the democratic process but instead created a fissure in the polity. The true wishes of the electorate were not respected by these fraudulent acts, thus making the polity a haven for political demagogues instead of being the pride of political statesmen.

The role of security personnel in the assessment of electoral security in Nigeria's democracy, particularly since the beginning of the Fourth Republic in 1999, indicates that the public has little trust in them (Chukwuma 2001). Nigeria's security sector consists of the army, police, Nigeria Security and Civil Defence Corps, and State Security Service. Section 214 of the 1999 Constitution lays down the functions of the Nigeria Police to include protection of life and property, the preservation of law and order, and the prevention and detection of crime (Nigeria's Constitution, 1999). The main election role of the police is to protect life and property, to preserve electoral law, to prevent and detect electoral crime, to maintain order and to create, by means of effective policing, a favourable climate in which a democratic election can take place (Electoral Bill 2006; INEC, 2011 and Rosenau et al. 2015).

Security personnel in most cases became despotic, aiding and abetting electoral irregularities in the country (Chukwuma, 2001; National Democratic Institute, 2012). In previous general elections during Nigeria's Fourth Republic - in 1999, 2003, 2007 and 2011 - they have used their authority, power, and access to firearms on many occasions to intimidate the population. In extreme situations, they have reacted violently to opposition parties which are supposed to be conducting lawful political campaigns or rallies, and have run into battle with civil society (Alemika, 2003; INEC, 2011; Jega, 2012; Oni et al 2013).

The 2015 general elections in Nigeria witnessed a dramatic turnaround in terms of its conduct and electronic procedures. The turnaround includes the introduction by the electoral umpire, INEC, of anti-electoral fraud procedures such as the use of the electronic smart card reader (SCR) and the permanent voter's card (PVC). This to a large extent minimised electoral fraud and malpractice in 
the electioneering process. This election is also significant because it was keenly contested and featured the strongest opposition to the ruling political party since the transition to civilian rule in 1999.

\section{Permanent Voter's Cards (PVCs)}

INEC introduced the use of PVCs for use in the 2015 general elections. This replaced the laminated paper temporary voter's card (TVC) which has many shortcomings for conducting a standard, zero malpractice and generally acceptable, free and fair election. Since the 2011 general elections the TVC has had a record of permitting high crime, flexibility, fraud and manipulation.

INEC produced PVCs for the 68833476 persons in the biometric register of voters ahead of the 2015 general elections (INEC 2015b; YIAGA 2015). The PVC replaced the TVC issued on the heels of voter registration after 2011. Quality, security, durability and cost effectiveness were underlying factors in the production of the PVCs by INEC. These cards have many components and specialised features such as base substrate, security printing, personalisation, lamination and chip embedding, with an average life span of ten years.

The PVC has an embedded chip that contains all the biometrics of a legitimate holder, including fingerprints and facial image. On election day the card is swiped on a smart card reader at the polling unit for authentication of the card and verification of the voter before voting commences. The PVC has security features that are not easily susceptible to counterfeiting. Only voters with their PVCs were allowed to vote in the 2015 general elections.

A pre-election verification of the PVC was carried out by INEC so that interested persons could do a prior check on their status in the register of voters by composing a short message in the following format: INEC, state of registration, last name, and the last five digits of the Voter Identification Number, and by sending an SMS to short code 20120. The PVCs are also made available for daily collection, including weekends, at distribution points in all 36 States and the Federal Capital Territory (FCT). The introduction of PVCs actually reduced election malpractice in the whole country and created a degree of serenity and relative trust in the electorate.

\section{The Electronic Card Reader}

For the first time in Nigeria's electoral history, electronic voter authentication systems, also called smart card readers, were deployed in the 2015 general elections. The card reader uses a highly secure cryptographic technology. This is commonly used in devices that need to perform secure transactions such as pay 
terminals. It has an ultra-low power consumption with a single core frequency of $1.2 \mathrm{GHz}$ and an Android 4.2.2 operating system. INEC has also introduced a backup system for the card readers - 36000 spare batteries and 25000 backup card readers that are positioned locally for quick delivery if needed (INEC 2015c).

The card reader units have been widely subjected to quality assurance, integrity and functionality testing, and found reliable in terms of ease of use, battery life and speed of processing. For instance, it takes an average of 10 seconds to authenticate a voter. The card readers were also subjected to stress testing in the 36 States and Federal Capital Territory (FCT) ahead of the 2015 elections. INEC made card readers available at every voting point in the States and FCT during the 2015 elections, with a substantial number of spares available to address contingencies (INEC 2015c).

Fraud continues to be a very serious problem in Nigeria's election environment, but it is gradually dwindling. Over 4.8 million voters were removed from the register after 2011 and the 2014 update for multiple registrations, while another 12 million were removed for incomplete information after the 2011 elections. The PVC and card readers are primarily a fraud prevention measure to prevent voters from being impersonated or disenfranchised through large-scale voter inflation. This is why the voter register has shrunk from 73 million registrations in the 2011 general elections down to 58 million before the continuous voter registration (CVR) of new voters, which brought it to 68 million voters ahead of the 2015 general elections.

\section{CHALLENGES OF ANTI ELECTORAL FRAUD PROCEDURES (AEFP) TECHNOLOGY IN NIGERIA}

The new technology introduced into the 2015 general elections encountered a number of challenges. These can be summarised as the technical malfunctioning of the machines, and the human errors in handling the machines. Apart from the menace of the Boko Haram insurgency which had led to the potential disenfranchisement of up to 1.5 million internally displaced persons (IDPs) for the 2015 general elections, there were concerns about violence around or after the elections based on religious, ethnic or regional divisions. Indeed, there had been a significant number of violent campaign incidents in all parts of the country resulting in at least 82 reported killings. The decision of INEC to postpone the elections by six weeks also gave rise to fears about vote rigging by the authorities (Nart 2015). However, to prosecute a credible election, INEC needed to verify the efficiency of the card reader in advance, and thus they conducted a mock election prior to the election in order to test the proposed system for the election (INEC 2015e; Sweeney 2015a). 
The elections were nevertheless bedevilled with problems. There was a poor level of awareness among the electorate about the card reader. A large number of Nigerians, especially those in rural communities, were completely unaware of the device. Many of these people had neither seen nor heard about the card reader until election day. The training given to the ad hoc and permanent INEC staff on the use of the card reader was inadequate. Most of the presiding officers and assistant presiding officers in the polling units were not effectively trained on the proper use and handling of the card reader and on the need to remove the film covering from the screen of the device to facilitate better fingerprint decoding. Of particular note was the failure of the card readers to recognise President Goodluck Jonathan's card and that of his wife Patience Jonathan. After four repeated trials and failures, Jonathan filled the incidence form and resorted to manual accreditation in order to vote.

Other challenges include the rejection of the PVC by the card readers, an inability to capture the biometrics from fingertips, and irregular capturing and fast battery drainage. INEC officials had to abandon the polling units and take the card readers back to their office for proper configuration. In order to salvage the situation INEC ordered the use of a manual process for accreditation. A number of the PVCs issued to voters by INEC could not be authenticated, thereby disenfranchising some eligible voters. In other cases voter cards were authenticated but their biometric data could not be verified after several trials. Even where they were verified, the process was in some cases very slow, especially with regard to fingerprints (Sweeney 2015a). Challenges concerning its use included possible battery failure to power the device and timeliness in verifying PVC holders, both of which reduced the numbers of voters confirmed in the accreditation process. Despite these concerns, Nigerians were generally optimistic that the technology had a positive impact on the voting process.

\section{THEORETICAL FRAMEWORK}

\section{Deprivation theory}

The theory of deprivation as applied in this work implies the deprivation due to unequal distribution of political, social and economic wealth. The theory does not claim that in all social groups there will be consensus in values; rather, it considers some of the consequences of situations where there is consensus. Where people do not agree on values, relative deprivation can also be noticed. This theory came out of a need to understand the motivations behind the social activist movements of the 1960s. It seeks to give answers to questions such as what impetus motivates an individual to agitate for change in his life. 
The theory posits that (collective) action stems from the individual's psychological reactions to the gap between expected circumstances and actual ones. The gap becomes apparent when they perceive themselves to be in a relatively unjust position vis-à-vis another person or group to which they might reasonably compare themselves (Tougas and Beaton 2002). For instance, an individual might expect to have access to an improved chance of electoral victory for a variety of reasons: he or she is of the right age, is obviously very intelligent, and has prepared by studying and adequate politicking. Other obvious facts that can degenerate into electoral violence and agitation may be the lack of expected access, which might create a perception of relative deprivation in comparison to people of similar age and status.

Alam (2013) also noted that the key to understanding the feeling of deprivation is a matter of which of these characteristics they are comparing themselves with. Why do they think they deserve better than they have? Who is their point of comparison? What choices do they think they should have open to them? Relative deprivation theorists have suggested that perhaps it is not ego relative deprivation (ERD) that motivates individuals, but rather perceptions of group or collective relative deprivation (CRD). CRD occurs when the individual feels that his or her group has been deprived. This is a major reason why the eruption of violence in Africa and in many developing economies is a prominent and regular event. Various groups and interests might suffer neglect and deprivation for a while but after some time their marginal propensity and elastic limit of forbearance is exceeded and therefore agitation, protest and violence inevitably ensues.

\section{METHODOLOGY}

The research methodology adopted is an empirical analysis of data from the Afrobarometer Round 6 survey. This is to assess the perception of Nigerians on their electoral environment and on INEC's level of preparedness, using a total sample of 2400 participants. INEC's officially released presidential election result is critically interrogated, validated and interpreted.

The sample selection technique is a simple proportionate purposive random sampling. Simple percentage, ratio and graphical illustrations are used to analyse the result. This research is appropriate because it reflects the true mindset of the populace regarding the apparently unending urban violence in their respective countries. It also reveals the perceptions of the people on the relevance of continuous democracy. 


\section{DISCUSSION OF FINDINGS}

The perception of Nigerians on their electoral environment and on INEC's level of preparedness is analysed according to the following criteria:

- election efficacy

- fear of political intimidation

- trust in INEC

- results of the 2015 presidential election

- voters' evaluation ratio to population evaluation

- voter analysis.

Table 1

Election Efficacy in Nigeria

\begin{tabular}{|l|c|}
\hline Rate & Percentage \\
\hline Not at all well & $28 \%$ \\
\hline Not very well & $40 \%$ \\
\hline Well & $19 \%$ \\
\hline Do not know & $4 \%$ \\
\hline
\end{tabular}

Source: Afrobarometer 2014

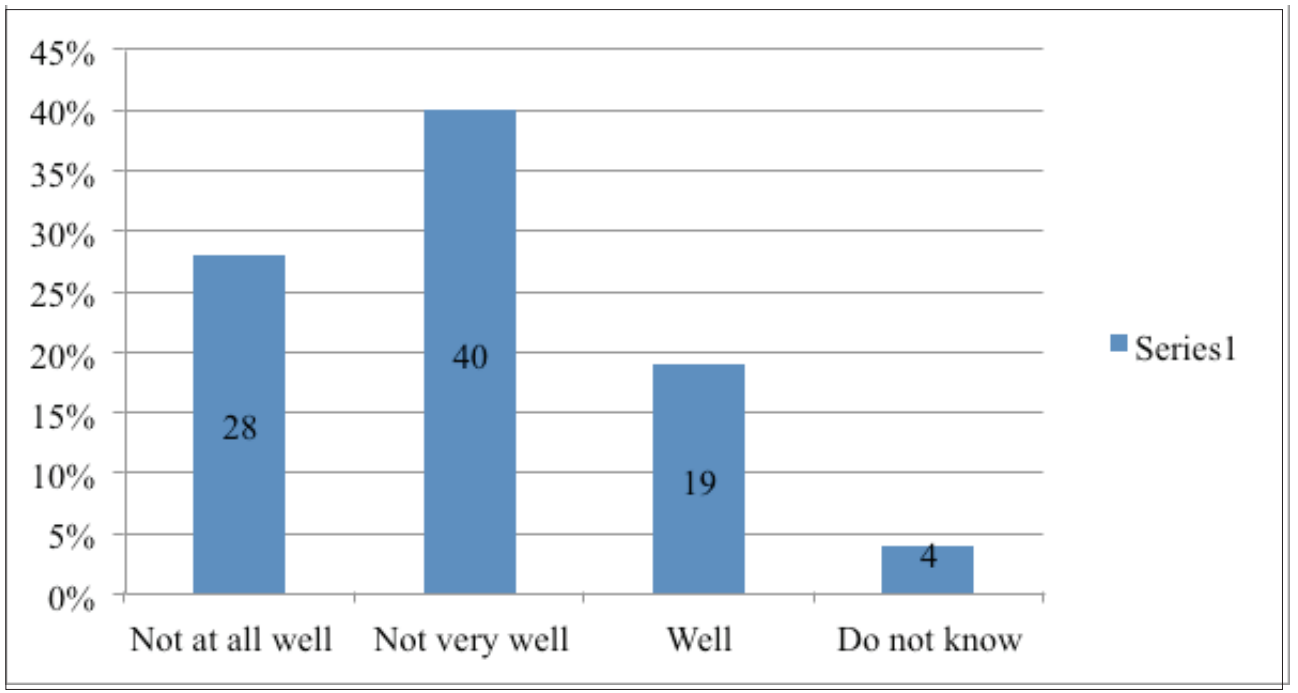

Figure 1: Election Efficacy in Nigeria 
From Table 1 above, it is evident that the perceived relevance of elections in Nigeria seems to be in a relative mature stage as $28 \%$ of the Nigerian electorates considers the efficacy of election to be not at all well; the highest percentage is in the relatively decisive stage with $40 \%$ of Nigerians seeing the efficacy of elections as not very well rooted in the polity. A total of $19 \%$ refers to the efficacy of the election as well. This is a relatively strong percentage comparing it with the not at all well perception.

\section{Table 2}

\section{Fear of Political Intimidation}

\begin{tabular}{|l|c|c|}
\hline Issues & 2012 & 2014 \\
\hline Somewhat / A lot & $34 \%$ & $50 \%$ \\
\hline A little/Not at all & $65 \%$ & $48 \%$ \\
\hline
\end{tabular}

Source: Afrobarometer 2014

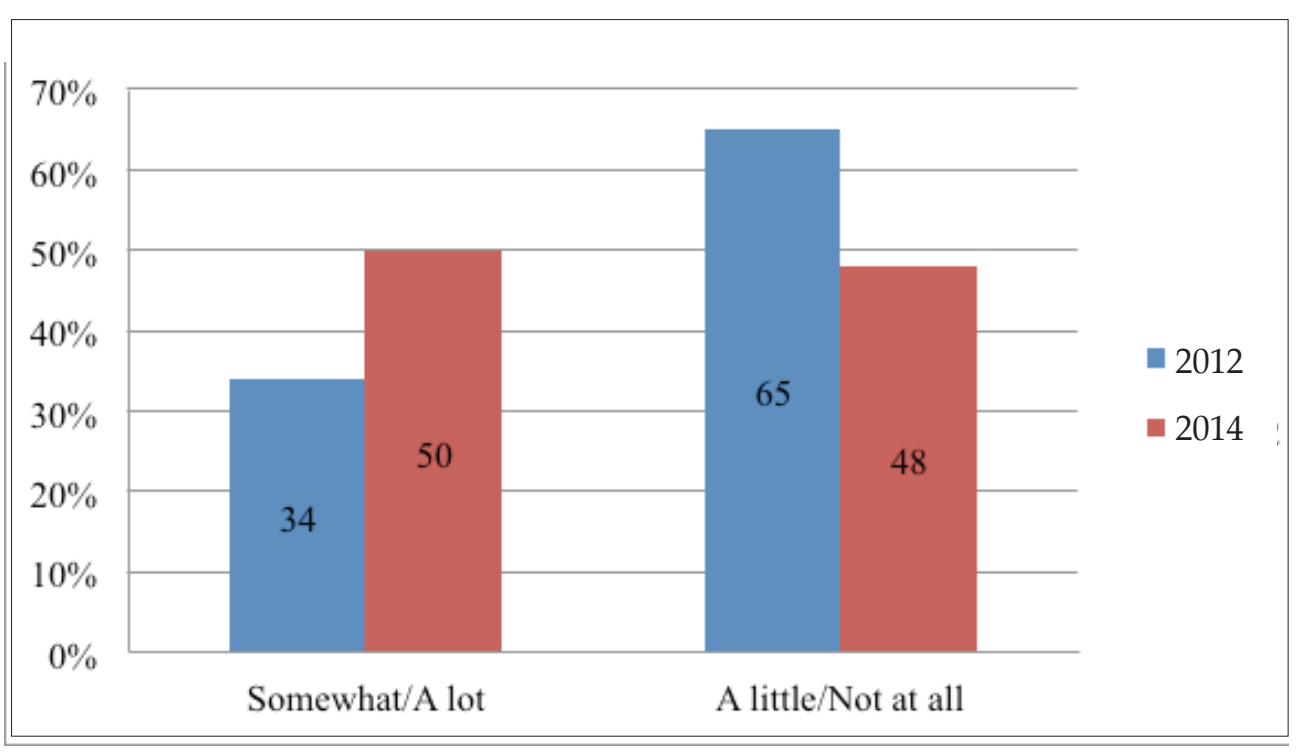

Figure 2 : Fear of Political Intimidation

Table 2 above indicates that the electoral atmosphere in Nigeria seems to be charged with political intimidation. But the intensity of the charge is seen to undulate from high to low at different intervals as the trend of political events changes. This might be a good sign that Nigeria's democracy is consolidating 
from one national electioneering period to the next. The perception of the fear of political intimidation as somewhat/a lot is 34\% in 2012, compared to 50\% in 2014. However, the perception of the fear of political intimidation as a little/not at all is 65\% in 2012, while it is 48\% two years later in 2014 .

Table 3

Trust in INEC

\begin{tabular}{|l|c|c|}
\hline Issues & $\mathbf{2 0 1 2}$ & $\mathbf{2 0 1 4}$ \\
\hline Not at all & $27 \%$ & $30 \%$ \\
\hline Just a little & $39 \%$ & $37 \%$ \\
\hline Some What & $27 \%$ & $25 \%$ \\
\hline A lot & $7 \%$ & $7 \%$ \\
\hline
\end{tabular}

Source: Afrobarometer 2014

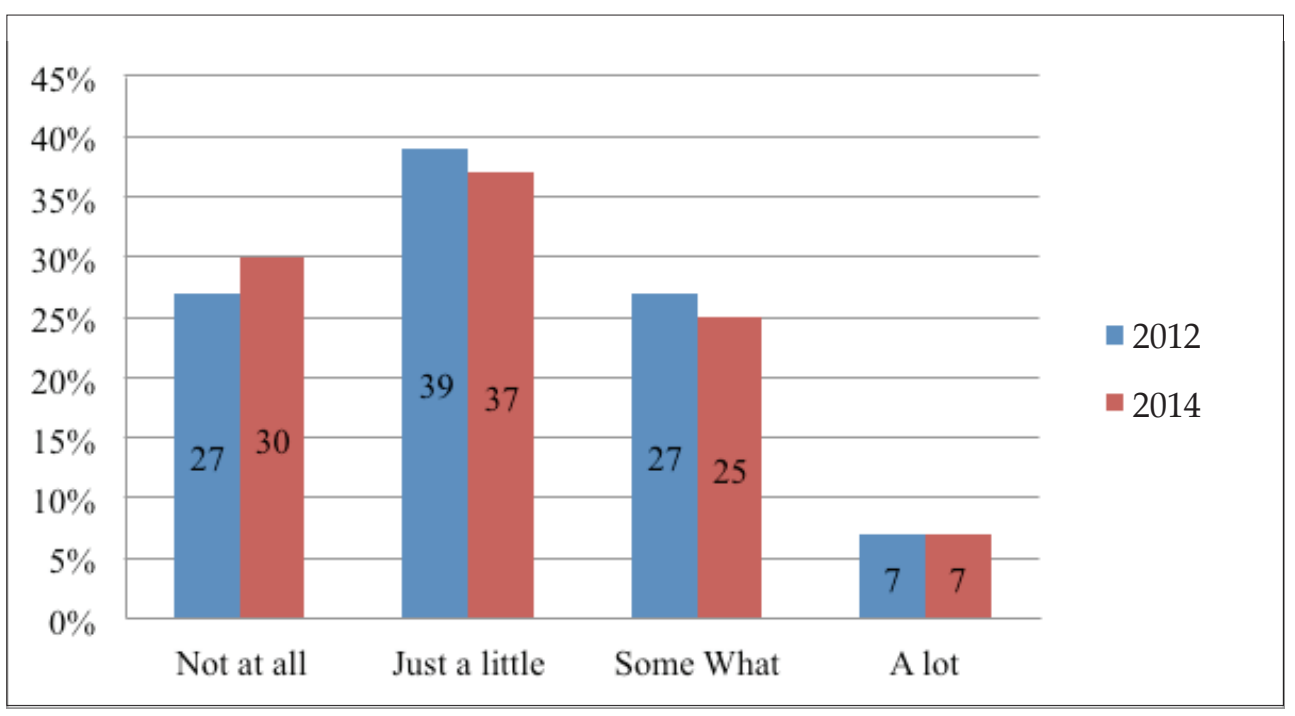

Figure 3: Trust in INEC

Figure 3 represents the relatively constant level of trust by Nigerians in the electoral body INEC. However the pendulum of this trust is swinging towards the low side. It is evident that a total of $73 \%$ of Nigerians had an appreciable level of trust for INEC in the year 2012, but this level had dropped to $69 \%$ in 2014. A total of $27 \%$ of Nigerians had no trust in INEC in 2012. This percentage increased slightly in 2014 to a record of 30\%. This data also corroborates the 2015 
pre- and post-election survey conducted by the International Foundation for Electoral systems (IFES). Their research revealed that public confidence in INEC is high and it increased dramatically by 16 points from pre-election (2014) to postelection (2015) levels of confidence (IFES 2015).

Table 4

2015 Presidential Election Result

\begin{tabular}{|r|l|c|c|}
\hline S/N & Political Party & Votes Recieved & Percentage \\
\hline 1 & APC & 15424921 & $53.96 \%$ \\
\hline 2 & PDP & 1853162 & $44.96 \%$ \\
\hline 3 & OTHERS & 1154000 & $1.08 \%$ \\
\hline
\end{tabular}

Source: INEC 2015d; IFES 2015

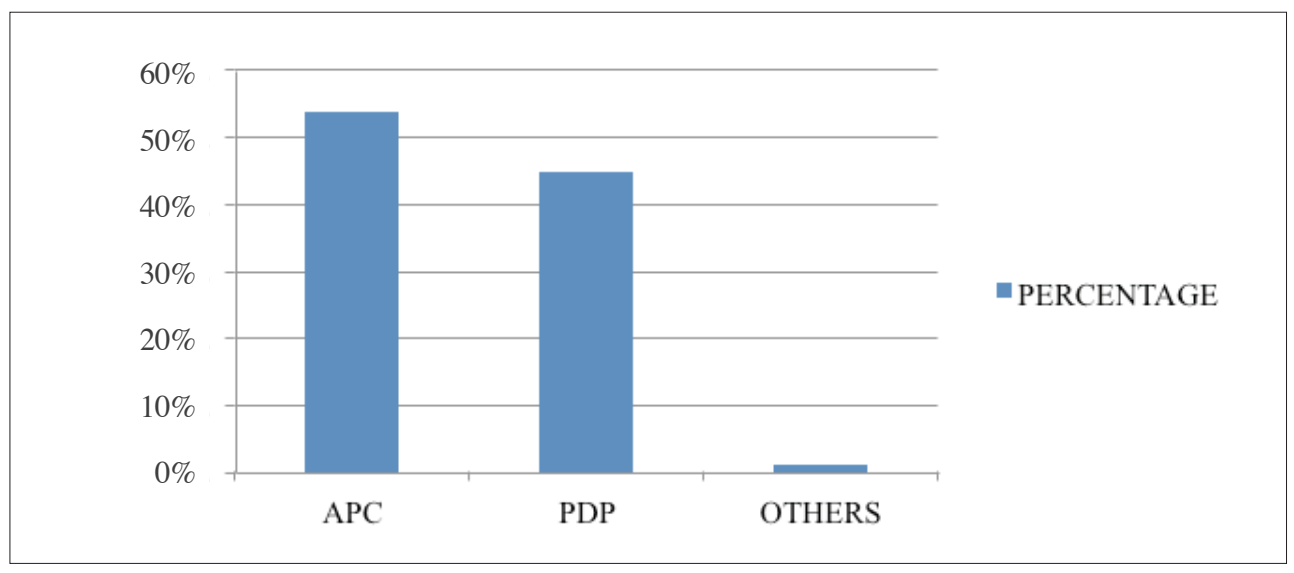

Figure 4: 2015 Presidential Election Result

The official INEC results of the 2015 presidential elections as shown in Table 4 above indicate that two major political parties have the majority of the votes and that neither of the two has an absolute majority. The parties in question are the All Progressive Congress (APC) and the Peoples' Democratic Party (PDP). The APC, with $54 \%$, has the largest percentage of votes, but it is important to note that this is not an absolute majority of votes cast. The PDP also have a large vote of about $45 \%$. The other 12 political parties had a total of about $1 \%$ of the total votes. There is no absolute majority winner in the polls but with a simple majority the winner was the candidate from the political party with the highest number of votes. 
Table 5

Ratio of Voters to General Population

\begin{tabular}{|c|c|c|c|c|c|}
\hline $\begin{array}{c}\text { Total Nigeria } \\
\text { Population }\end{array}$ & $\begin{array}{c}\text { Total } \\
\text { Electorate }\end{array}$ & $\begin{array}{c}\text { Total } \\
\text { Accredited } \\
\text { Voters }\end{array}$ & $\begin{array}{c}\text { Total } \\
\text { Valid } \\
\text { Votes }\end{array}$ & $\begin{array}{c}\text { Total } \\
\text { Rejected } \\
\text { Votes }\end{array}$ & $\begin{array}{c}\text { Total } \\
\text { Votes Cast }\end{array}$ \\
\hline 183523432 & 68833476 & 31756490 & 28587564 & 844519 & 29432083 \\
\hline
\end{tabular}

Source: INEC (2015d) and United Nations (2015)

Table 6

Percentage of Voters and Non-voters

\begin{tabular}{|c|c|c|c|}
\hline $\begin{array}{c}\text { Percentage of } \\
\text { Electorate in Total } \\
\text { Population }\end{array}$ & $\begin{array}{c}\text { Percentage of } \\
\text { Population not } \\
\text { Voting }\end{array}$ & $\begin{array}{c}\text { Total Electorate } \\
\text { Accredited }\end{array}$ & $\begin{array}{c}\text { Total Electorate } \\
\text { Accredited but Did } \\
\text { Not Vote }\end{array}$ \\
\hline $37.51 \%$ & $62.45 \%$ & $53.86 \%$ & $7.32 \%$ \\
\hline
\end{tabular}

Source: INEC (2015d)

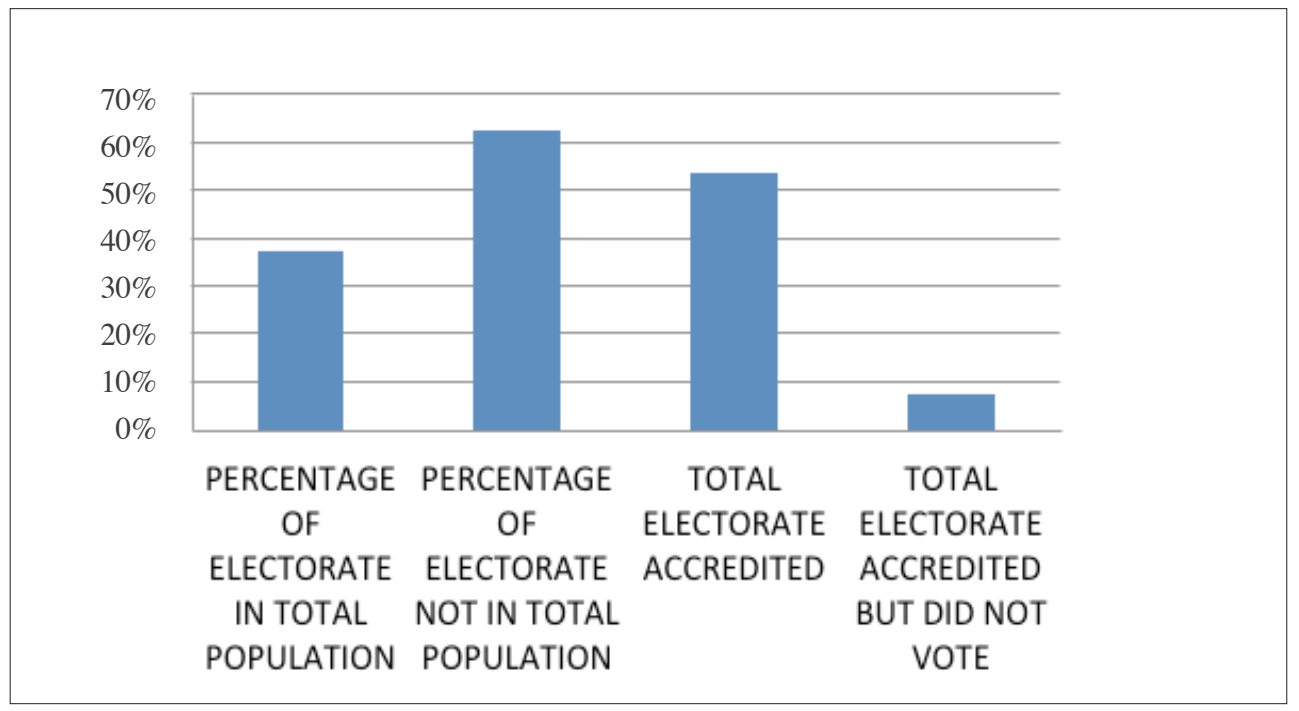

Figure 6: Percentage of Voters and Non-voters 
Tables 5 and 6 indicate that the electorate in 2015 consisted of nearly $38 \%$ of Nigeria's population. The remaining $63 \%$ consists of the non-voting population. The fact that two-thirds of the country's population played no active role in determining political leadership is an issue for concern and cannot be considered adequate for democracy and majority rule in any democracy.

It is also evident that nearly $54 \%$ of the total electorate were not accredited and just over $7 \%$ of accredited voters did not vote. This means that the real number of the electorate reduces by nearly $54 \%$. Of the remaining $46 \%$ that were accredited for the elections, about $7 \%$ of the total number of accredited voters did not vote.

Table 7

Voter Analysis

\begin{tabular}{|c|c|}
\hline $\begin{array}{c}\text { Percentage of Total Accredited Voters to } \\
\text { Total Electorates }\end{array}$ & $\begin{array}{c}\text { Percentage of Total Vote Cast to Total } \\
\text { Accredited Voters }\end{array}$ \\
\hline $46.14 \%$ & $92.68 \%$ \\
\hline
\end{tabular}

Source: INEC (2015d)

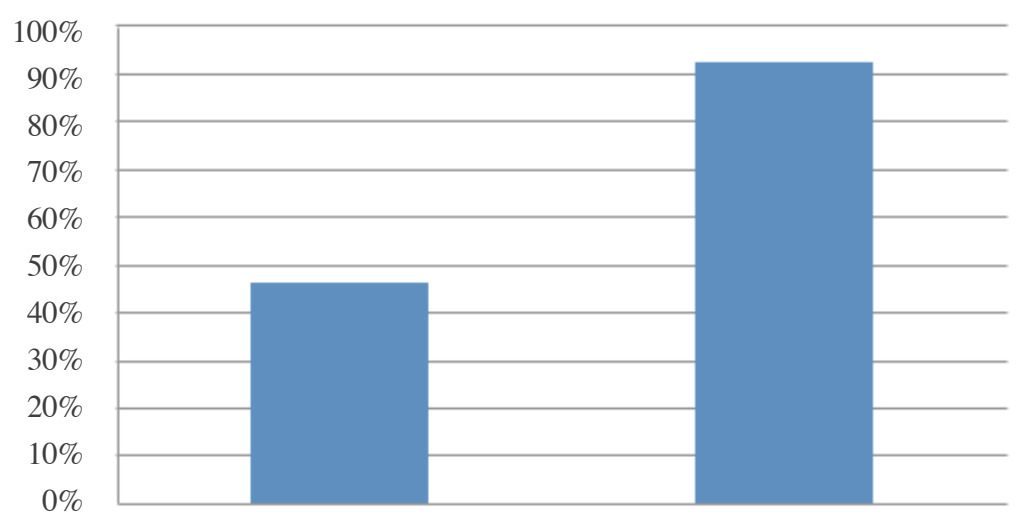

PERCENTAGE OF TOTAL PERCENTAGE OF TOTAL ACCREDITED VOTERS TO VOTE CAST TO TOTAL TOTAL ELECTORATES ACCREDITED VOTERS

Figure 7: Voter Analysis 
From Table 7 above it is evident that the percentage difference of the total accredited voters to the total number of electorate is about $46 \%$. About $7 \%$ of the total number of accredited voters did not vote. This means that of the total accredited voters nearly $93 \%$ voted. This implies that of the total accredited Nigerian electorate, a few did not vote. This does not speak of a fully informed electorate and a mature democratic set up.

\section{THE BAILOUT STRATEGIES}

For future elections to be more free, fair, equitable and widely acceptable, all the stakeholders should consider the following bailout as inevitable. These concerned stakeholders include: INEC, the executive arm of government, the legislative arm of government, the electorate, international organisations and the citizenry.

INEC should also treat logistical problems with the same importance as the announcement of election results. All electoral materials, both sensitive and nonsensitive, should be ready at least two months before election day so as to prevent emergencies and postponements. INEC should also ensure transparency and nonpartisanship in its conduct with both political parties and political zones to prevent the electorate from being biased towards the electoral process. Finally, voter registration should be continuously upgraded, permanent voter cards should be issued and the use of the card reader machine should be maintained in future electoral processes.

The interference of the president in INEC functions should be limited to the appointment of the INEC chairman and commissioners, and this should be done in conjunction with the National Assembly so as to have a majority approval of citizen representatives. The police and other security agents should join hands, under the direction of INEC, in escorting INEC materials to their destinations and securing staff during the elections. This will restrict their duties to security and monitoring instead of harassing the electorate and supporting political parties in campaigning.

The legislature should pass laws to give the INEC full financial autonomy, not linked to the executive or to political parties, so as to have a nonpartisan electioneering process. The disbursement of such finances should be as and when needed. Also, there should be vigilant oversight function of how INEC spends this money. The Electoral Act should not be designed to suit any particular political party but further strengthened to enhance equitability and fairness to all contestants across board.

The electorate on their part should consider their votes as of paramount importance. This will make electioneering, from registration to voting, a process of true value. The electorate should ensure that they are available for electioneering 
activities from registration to the declaration of results at each polling unit, so as to ensure a full democratic consolidation with free and fair processes.

International organisations should sustain their monitoring roles in the electioneering process so as to help check undemocratic practices that may interfere in the process. Their financial assistance and support to the government for the election process should also be monitored so as to prevent any diversion of money for personal or political party use. Their technical expertise should be directed towards the area where they are needed and not to issues that had been resolved locally.

The general populace, which comprises both the electorate and those not qualified to vote, should ensure that they act as watchdogs to the daily actions and reactions of the INEC and other stakeholders, so that the much esteemed democratic process will be balanced, free and fair. Both the electorate and nonvoting age groups should be free to participate in terms of positive criticism and constructive opinion on the electioneering processes.

\section{CONCLUSION}

Nigeria's 2015 general election took a new direction in its patterns, processes and procedures. The introduction of anti-fraud electoral procedures made people think more about the level of trust in the electoral body, INEC, for ensuring a credible election. The level of acceptability of all electoral processes is highly significant both within the country and beyond its shores. The level of violence recorded during the presidential election was minimal, which shows that the political behaviour of the Nigerian electorate is concerned with consolidating a sustainable democracy.

The deprivation theory adapted in this study showed that a significant number of Nigerians were interested in what the politicians would give them as compensation for voting or campaigning during this period. Others accepted financial inducements and opted for political street gang duty for some desperate politicians. However, the level of security for the election was adequate for a peaceful, relatively free and fair poll.

The research question in this study was interrogated by the methodology adopted. This shows that the positive perception of Nigerians about their electoral environment and of INEC's level of preparedness is relatively high. This was seen from the perception of the election environment, fear of political intimidation and the level of trust in INEC. The analysis of the official INEC presidential results, voter turnout and the performance of the political parties, all show a significant improvement in Nigeria's democracy. 
The research revealed that the electorate was not afraid of political intimidation, the level of INEC preparedness was high and the level of popular trust in INEC also increased significantly from the pre-election year to the election year. Also the use of technology such as the permanent voter's card and the card reader machine add credibility to the electoral processes. These new technologies, however, had several flaws which can be mitigated in subsequent elections through continuous improvement in the training of ad hoc INEC staff and awareness of its usage by the general populace. These flaws contributed to the decreased output of the total number of registered voters and to the final tally of votes cast at the end of the election.

\section{- REFERENCES -}

Abdullahi, A 2015, 'Promoting credible elections in developing countries: International development partners and civil society organizations in Nigeria', African Journal of Political Science and International Relations, vol. 9, no. 5, 190-199.

Alemika, E 2003, 'Police, Policing and Rule of Law in Transitional Countries', in L Alam, S 2013, 'Relative Deprivation Theory, Nationalism, Ethnicity and Identity Conflicts', Geopolitics Quarterly, vol. 8, no 4.

Butts, K \& Metz, S 2015, Armies and democracy in the New Africa: lessons from Nigeria and South Africa. DIANE Publishing.

Chukwuma, I 2001, 'Police Transformation in Nigeria: Problems and Prospects in Crime and Policing in Transitional Societies', Institute of International Affairs Johannesburg South Africa Seminar Report, no. 8.

Gberie, L 2011, The 2011 elections in Nigeria: A new dawn? Situation Report Institute for Security Studies.

http:/ / www.obsafrique.eu/wp-content/ uploads/2011/05/13May2011Nigeria.pdf Accessed on 12/10/2013.

Goldsmith, A 2015, 'Elections and civil violence in new multiparty regimes: Evidence from Africa', Journal of Peace Research.

Gyimah-Boadi, E 2015, 'Africa's Waning Democratic Commitment', Journal of Democracy, 26(1), 101-113.

IFES 2015, Knowledge and Perceptions of the Independent National Electoral Commission Nigeria 2015 Post-Election Survey, IFES Nigeria. https://www.ifes.org/ sites / default/files / nigeria_post-election_infographic_2015_-_knowledge_and_ perceptions_of_inec_logo.pdf

INEC 2011, Report on the 2011 General Elections. Abuja: Independence National Electoral Commission INEC Nigeria. 
http: / / www.inecnigeria.org/wp-content/ uploads / 2013/07/ REPORT-ON-THE2011-GENERAL-ELECTIONS.pdf Accessed on 12/10/2013.

INEC 2015b, Every Validly Registered Voter Will Get PVC INEC Nigeria. Accessed on $2 / 4 / 2015$. http:/ / www.inecnigeria.org/ ?inecnews=every-validly-registeredvoter-will-get-pvc-inec-chair

INEC 2015c, INEC Question and Answer on PVCs and Card Readers

INEC Nigeria. http:/ / www.inecnigeria.org/ ?inecnews=factsheets-on-theelectoralprocessandsituationroom.placng.org

INEC 2015d, Presidential Result Summary Sheet. INEC Nigeria.

INEC 2015e, INEC News: Every Validly Registered Voter Will Get PVC - INEC

Chair http:/ / www.inecnigeria.org/ ?inecnews=every-validly-registered-voterwill-get-pvc-inec-chair

Jega, A 2012, 'The Electoral Process and Security Sector Synergy', Paper Delivered to EIMC 6 Participants of Institute for Security Studies (ISS). Abuja. August 21. Jega, A \& Hillier, M 2012, 'Improving elections in Nigeria: Lessons from 2011 and looking to 2015', Lecture delivered at Chatham House, London, 5.

Lauren, B 2015, Nigeria's 2015 Elections and the Boko Haram Crisis. Congressional Research Service 7-5700.

Lindholt et al. (eds.) Police, Rule of Law in Transitional Societies: Centre for Human Rights and Kluwer Publishers, Denmark.

NationalDemocraticInstitute2012, Final Reporton the 2011 Nigerian General Elections. National Democratic Institute for International Affairs Washington, DC.

Nigeria. National Assembly 2006. Bill for an act to regulate the conduct of elections in the federal, state and local governments, and the registration of voters and matters connected therewith. Nigeria.

Nart, J. 2015, Election Observation Delegation to the Presidential and Parliamentary Elections in Nigeria (26-30 March 2015). European Union Election Observation Mission Report.http:/ / www.europarl.europa.eu/intcoop/election_observation/ missions / 2014-2019/2015_03_28_nigeria.pdf

Omotola, S 2010, 'Elections and democratic transition in Nigeria under the Fourth Republic', African Affairs vol. 109, Issue 437, pp 535-553.

Oni S, Chidozie F \& Agbude A. 2013, 'Electoral Politics in the Fourth Republic of Nigeria's Democratic Governance', Developing Country Studies vol.3, no.12.

Rosenau W, Mushen E, \& McQuaid J, 2015, 'Security During Nigeria's 2015

National Elections: What Should We Expect From the Police?', CNA's Occasional Paper 3003, Washington Boulevard, Arlington, VA 22201.

Sweeney, B. 2015a, Nigeria's Election Commission Introduces New Technologies and Processes for the 2015 Vote, International Foundation of Electoral System (IFES). https://www.ifes.org/news/nigerias-election-commission-introducesnew-technologies-and-processes-2015-vote

Sweeney, B 2015b, Nigeria's 2015 Elections: A Critical Vote for Democracy in 
Africa.International Foundation of Electoral System (IFES) https://www.ifes. org/news/nigerias-2015-elections-critical-vote-democracy-africa

The National Human Rights Commission of Nigeria 2015, A Pre-Election Report And Advisory on Violence in Nigeria's 2015 General Elections. National Human Rights Commission of Nigeria.

Tougas, F \& Beaton, A 2002, 'Personal and Group Relative Deprivation: Connecting the ' $\mathrm{I}$ ' to the 'We' in Walker I. \& Smith H. (eds) Relative Deprivation: Specification Development and Integration. Cambridge University Press, Cambridge, UK.

YIAGA 2015, Youth Observatory Report on the collection of PVC .Youth Initiative for Advocacy Growth and Advancement, Abuja, Nigeria.

United Nations 2015, Elaboration of data by United Nations, Department of Economic and Social Affairs, Population Division. Worldometers www.Worldometers.info 